\title{
Cloning of $\alpha$-L-arabinofuranosidase Genes and Its Expression in Escherichia coli: A Comparative Study of Recombinant Arabinofuranosidase Originating in Bacillus subtilis DB104 and Newly Isolated Bacillus licheniformis CW1
}

\author{
MOCHAMAD NURCHOLIS ${ }^{1,2}$, NIKNIK NURHAYATI ${ }^{1}$, IS HELIANTI $^{1}$, MARIA ULFAH $^{1}$, \\ BUDIASIH WAHYUNTARI ${ }^{1}$, AND AGUSTIN KRISNA WARDANI ${ }^{2}$
}

\author{
'Center for Bioindustrial Technology, Badan Pengkajian dan Penerapan Teknologi, \\ Jalan MH Thamrin 8, Jakarta 10340, Indonesia; \\ ${ }^{2}$ Department of Food Technology, Faculty of Agricultural Technology, Universitas Brawijaya, \\ Jalan Veteran, Malang 65145, Indonesia
}

\begin{abstract}
Arabinofuranosidase (Abfa) is one of the most important enzymes involved in degradation of lignocelullose biomass. Two genes encoding $\alpha$-L-Arabinofuranosidase (abfA), each from Bacillus subtilis DB104 (abfAal) and an indigenous Indonesian $B$. licheniformis CW1 (abfAb3), were cloned by the PCR approach and expressed in Escherichia coli. Sequences analysis of abfAal and $a b f A b 3$ revealed that each consists of 1721 and 1739 base pairs long DNA, respectively. Each clone contains a hypothetical open reading frame of 1503 and 1509 bp that encode an Abfa protein of 500 and 502 amino acids for $a b f A a 1$ and $a b f A b 3$, respectively. The deduced amino acid sequence of AbfaB3 shares 75\% identity to that of AbfaA1. The recombinant enzymes were expressed constitutively in E. coli. Partial characterization of those enzymes revealed that the AbfaA1 and AbfaB3 were optimally active at $50{ }^{\circ} \mathrm{C}$ and $60^{\circ} \mathrm{C}$ at $\mathrm{pH} 6$, respectively. Thermostability studies of the recombinant enzymes with p-nitrophenyl $\alpha$-L-arabinofuranoside at their optimal conditions showed that up to $50 \% \mathrm{AbfaA} 1$ activity was lost after $5 \mathrm{~h}$ incubation at $50{ }^{\circ} \mathrm{C}$, whereas the $\mathrm{AbfaB} 3$ retained its activity over $75 \%$ after $12 \mathrm{~h}$ pre-incubation at $60{ }^{\circ} \mathrm{C}$. This thermostability study of recombinant $\mathrm{AbfaB} 3$ showed for the first time that the arabinofuranosidase from $B$. licheniformis is a thermostable enzyme. The recombinant enzyme showed a higher optimal reaction temperature $\left(60^{\circ} \mathrm{C}\right)$ in comparison to the previously reported thermostable arabinofuranosidase. The thermostable AbfaB3 has a potential to be applied to the degradation of lignocellulose biomass synergistically with thermostable xylanases, for instance in the production of xylo-oligosaccharides.
\end{abstract}

Key words : $\alpha$-L-arabinofuranosidase, Bacillus, cloning, thermostability

Arabinofuranosidase merupakan salah satu enzim penting dalam degradasi biomassa lignoselulosa. Gen yang mengkodekan $\alpha$-L-Arabinofuranosidase ( $a b f A$ ) masing - masing dari Bacillus subtilis DB104 (abfaAl) dan isolat asli Indonesia $B$. licheniformis CW1 ( $a b f a B 3$ ) telah diklon dengan pendekatan PCR dan diekspresikan dalam Escherichia coli. Analisa sekuen abfAal dan abfAb3 menunjukan bahwa masing-masing klon secara berurutan mengandung DNA berukuran 1721 dan 1739 bp. Masing-masing klon DNA terdiri dari satu hipotetis kerangka pembacaan terbuka berukuran 1503 dan 1509 bp yang mengkodekan protein Abfa berukuran 500 dan 502 asam amino secara berurutan untuk klon AbfAa1 dan AbfAb3. Urutan asam amino hasil deduksi AbfaB3 mempunyai kemiripan 75\% terhadap AbfaA1. Enzim rekombinan diekspresikan secara konstitutif pada E. coli. Karakterisasi parsial dari enzim tersebut menunjukkan bahwa AbfaA1 dan AbfaB3 masing-masing bekerja secara optimal pada suhu $50{ }^{\circ} \mathrm{C}$ dan $60{ }^{\circ} \mathrm{C}$ pada $\mathrm{pH}$ 6. Studi termostabilitas enzim rekombinan menggunakan para-nitrophenyl $\alpha$-L-arabinofranoside pada kondisi optimalnya memperlihatkan bahwa aktivitas AbfaA 1 turun hingga $50 \%$ setelah diinkubasi selama 4 jam pada suhu $50{ }^{\circ} \mathrm{C}$, sementara $\mathrm{AbfaB} 3$ mempertahankan aktivitasnya hingga lebih dari $75 \%$ setelah 12 jam inkubasi pada suhu $60{ }^{\circ} \mathrm{C}$. Studi termostabilitas AbfaB3 rekombinan ini memperlihatkan untuk pertama kalinya bahwa arabinofuranosidase dari B. licheniformis merupakan enzim termostabil. Enzim rekombinan ini memperlihatkan suhu optimal reaksi yang lebih tinggi dibandingkan dengan enzim termostabil yang telah dilaporkan sebelumnya. AbfaB3 termostabil ini potensial untuk digunakan dalam proses degradasi biomassa lignoselulosa secara sinergis dengan enzim xilanase termostabil dalam proses produksi xilooligosakarida.

Kata kunci: $\alpha$-L-arabinofranosidase, Bacillus, kloning, termostabilitas

In the last few decades, bioconversion of lignocellulosic biomass has received a great deal of attention because of its potential application in various agro-industrial processes especially in the production

*Corresponding author, Phone: +62-21-7560536 ext 124, Fax:+62-21-7566922, E-mail : nikniknur@gmail.com of renewable biofuel (Keshwani and Cheng 2009; Sanchez and Cardona 2008) and chemicals such as xylo-oligosaccharides (Akpinar et al. 2009), protein (Bals et al. 2007), 2,3-butanediol (Saha and Bothast 1999), and ferulic acid (Hunhammar et al. 1997). Alpha-L-arabinofuranosidases (abfa, EC 3 2.1.55) are exo-type enzymes that catalyze the hydrolysis of the 
non reducing terminal $\alpha$-L-arabinofuranosidic linkage in hemicellulose such as arabinoxylan, arabinan and other L-arabinose containing polysaccharide. These enzymes act synergistically with other hemicellulases, such as mannanase, xylanase, and acetyl xylan esterase to degrade the hemicellulose backbone completely (Ross et al. 1992; Gilead and Shoham 1995). As a debranching enzyme $\alpha$-L-arabinofuranosidase is one of hemicellulases that seems to be critical in the early steps of hemicellulose degradation (Jeffries 1990).

Various attempts have been developed to obtain arabinofuranosidase enzymes including direct purification of those native enzymes (Kaneko et al. 1994; Gilead and Shoham 1995; Degrassi et al.2003; Raweesri et al.2008) as well as over-expressing their recombinant enzymes (Whitehead and Hespell 1995; Morales et al. 1995; Pei and Shao 2008). This view is supported by the genetic information accessible from GenBank (www.ncbi.nlm.nih.gov/ genbank). Gene cloning and its expression in host cells such as E. coli, Bacillus, or yeasts have become a promising method of choice.

The objectives of the current study were to clone the two genes encoding $\alpha$-L-arabinofuranosidase from Bacillus subtilis DB104 and a newly isolated and identified strain $B$. licheniformis $\mathrm{CW} 1$, as well as to express the cloned genes in E. coli. Characteristics of both recombinant enzymes were compared to select for a thermostable arabinofuranosidase having an optimum reaction temperature not less than $60{ }^{\circ} \mathrm{C}$, which has the potential to be applied synergistically along with thermostable xylanases in xylooligosacharide production from lignocellulosic biomass. This is usually conducted in a reaction temperature not less than $60^{\circ} \mathrm{C}$.

\section{MATERIALS AND METHODS}

Bacterial Strains and Culture Conditions. $B$. subtilis DB104 and B. licheniformis CW1 were obtained from BPPT Culture Collection. The strains were grown at $37^{\circ} \mathrm{C}$, shaken at $150 \mathrm{rpm}$ for $16-18 \mathrm{~h}$ in LB medium ( $\mathrm{pH} 7.2$ ) containing $10 \mathrm{~g}$ soy peptone, $10 \mathrm{~g}$ $\mathrm{NaCl}$, and $5 \mathrm{~g}$ yeast extract per liter. For gene cloning and protein expression E. coli strain $\mathrm{DH} 5 \alpha$ was employed and grown in LB medium containing ampicillin $\left(100 \mu \mathrm{g} \mathrm{mL}^{-1}\right)$.

16S rDNA-Based Identification. Bacillus CW1 isolate was identified by $16 \mathrm{~S}$ rDNA-based amplification using universal primers for eubacterial rRNA genes, 9F (5'-AGAGTTTGATC(C/A)TGGCTC
AG-3') and 1510R (5'GTTAC(G/C)TTGTTACGAC TT-3') (Dhiaf et al. 2008). The partial 16S rRNA gene sequence was analyzed and compared with known bacterial sequences in the NCBI GenBank using the BLAST program (http://blast.ncbi.nlm.nih.gov /Blast.cgi) and submitted to GenBank (www.ncbi. nlm.nih.gov/genbank).

Cloning of $\alpha$-L-arabinofuranosidase-Encoding Genes. Genomic DNA was each extracted from $B$. subtilis $\mathrm{DB} 104$ and $B$. licheniformis $\mathrm{CW} 1$ according to the phenol/chloroform protocol developed by Sambrook and Russel (2001). The genes encoding $\alpha$-Larabinofuranosidases were each amplified by PCR from the genomic DNA using the following primer pairs: Abfabs-F (5'GACTAGTTAGTTCGGTCGAAA GAAATGTTTACGC-3') and Abfabs-R (5'-GAAGAT CTTTA TGACTGTTTTTTCAGGCGGATCAC3') for abfAal, Abfabl-F (5'ATGGTACCTAACGCTCCCAA TCGGACTGT3') and Abfabl-R (5'GCGAGATCTTC ATTGTTTCTTCATTCTGAT3') for $a b f A b 3$. Primers used were based on nucleotides sequences of $\alpha-\mathrm{L}$ arabinofuranosidase genes of $B$. subtilis 168 (GenBank NC_000964) and B. licheniformis DSM13 (GenBank NC_006322). The amplified genes were each cloned into pGEM-T Easy vector (Promega, Madison) according to the manufacturer's protocol. Positive clones were verified by restriction endonuclease analysis of the recombinant plasmids by using EcoRI and assays of their expressed recombinant protein against specific substrat para-nitrophenyl arabinofuranoside.

Sequence Analysis. Identification of the 16S rDNA and arabinofuranosidase genes were performed by using Basic Local Alignment Search Tool (BLAST, National Center for Biotechnology Information) available at http://blast.ncbi.nlm.nih.gov/Blast.cgi with the standard parameters. Nucleotide sequences were aligned using Clustal W version 11 (Thompson et al. 1994) that is accessable as public web server at http://align.genome.jp/. The alignments were visually edited when necessary using GeneDoc (Nicholas and Nicholas 1997). The nucleotide sequence of the clone B3 containing the $\alpha$-L-arabinofuranosidase gene of $B$. licheniformis CW1 was deposited in the GenBank database under accession number JN967641.

Enzyme Production. E. coli transformants harbouring recombinant plasmids containing arabinofuranosidase gene were cultivated in $50 \mathrm{ml} \mathrm{LB}$ media containing ampicillin. Cells were harvested from the overnight culture by centrifugation at $4025 \mathrm{xg}$ (Rotor R10A, Hitachi) $4{ }^{\circ} \mathrm{C}$ for $5 \mathrm{~min}$. The pellet 
obtained was resuspended in $5 \mathrm{~mL}$ citrate buffer $\mathrm{pH} 6$, and disrupted by sonication (Heat system XL ultrasonicator) at the maximum frequency $(20 \mathrm{kHz})$ for $20 \mathrm{~s}$ on and $20 \mathrm{~s}$ off repeatedly for 5 minutes at $4{ }^{\circ} \mathrm{C}$. The crude extracts containing recombinant enzyme were then recovered by centrifugation for $10 \mathrm{~min}$ at $5800 \mathrm{xg}$.

Enzyme Assay. The arabinofuranosidase assay was based on the hydrolysis of para-nitrophenyl $\alpha$-Larabinofuranoside (pNP-A) (Sigma-Aldrich, USA) described by Martinez et al. (2006) with slight modification. The routine assay contained $175 \mu \mathrm{L}$ of appropriately diluted enzyme sample, $175 \mu \mathrm{L}$ of 50 $\mathrm{mM}$ citric acid- $\mathrm{Na}_{2} \mathrm{HPO}_{4}$ buffer $(\mathrm{pH} 6)$ containing 1 $\mathrm{mM}$ of pNP-A. Mixtures were incubated at $40^{\circ} \mathrm{C}$ for 20 $\mathrm{min}$, and the reaction terminated by the addition of 700 $\mu l$ of $1 \mathrm{M} \mathrm{Na}_{2} \mathrm{CO}_{3}$. The colour intensity of the released para-nitrophenol was measured at $405 \mathrm{~nm}$. One unit of activity was defined as the amount of enzyme that produces $1 \mu \mathrm{mol}$ of p-nitrophenol per min under the assay conditions used (Martinez et al. 2006). The unit activity of enzyme is expressed in units of activity per $\mathrm{mg}$ of total protein (specific activity). The protein quantification was measured by the Bradford method with Bovine Serum Albumin (BSA) as standard (Bradford, 1976).

Effects of pH and Temperature on Arabinofuranosidase Activity. The effect of temperature on the activity of $\alpha$-L-arabinofuranosidase was investigated in the reaction mixtures containing 50 $\mathrm{mM}$ citric acid- $\mathrm{Na}_{2} \mathrm{HPO}_{4}$ buffer ( $\mathrm{pH} 6$ ) by measuring the activity using pNP-A at specific temperatures ranging from $30-70{ }^{\circ} \mathrm{C}$. The activity of $\alpha$-Larabinofuranosidase over a $\mathrm{pH}$ range of 5-9 was analyzed by reacting the enzyme at their optimal temperatures in three different buffers $(50 \mathrm{mM})$ : citric acid- $\mathrm{Na}_{2} \mathrm{HPO}_{4}$ (pH 5 to 6), phosphate buffer (pH 7 to 8), Tris-HCl buffer (pH 9) (Gilead and Shoham 1995) using the routine assay. The results were expressed as a percentage of the activity obtained at either the optimum $\mathrm{pH}$ or the optimum temperature (Canakci 2007).

Thermostability. Temperature stability of $\alpha$-Larabinofuranosidase enzymes was studied by incubating them at their optimal temperatures in the absence of the pNP-A substrate. At various time intervals, an aliquot of the enzyme was removed and placed on ice. The residual enzymatic activity of each enzyme aliquot was determined by routine assay. The results were expressed as a percentage of residual activity calculated on the basis of the unheated sample. Enzyme thermostability was evaluated by determination of decimal reduction time (D-Value) and half life $\left(t_{1 / 2}\right)$. $D$-value is defined as the time exposure required to reduce $90 \%$ of initial residual activity of arabinofuranosidase at a constant temperature (Wahyuntari and Suhartono 2002). The D-value was determined from the negative reciprocal of the slopes of the regression lines, using the linear portions of the residual activity versus time of exposure at constant temperature (as per Equation 1):

$$
\log (A)=\log \left(A_{0}\right)-t / D
$$

in which, $A$ is the actual enzyme activity, $A_{0}$ is the enzyme activity before exposure to heat, $t$ is length of time of heating, and $\mathrm{D}$ is decimal reduction time. The time at a specified temperature required for loss of $50 \%$ activity (half life) was calculated based on the equation 1 (Wahyuntari and Suhartono 2002).

\section{RESULTS}

16S rDNA-Based Identification. An indigenous bacterium CW1 isolate collected by BPPT-Cullture Collection was used as the genetic source in this work. This bacterial strain was isolated from Ciseeng Hot Spring, West Java, Indonesia. Partial sequencing of the amplified 16S rDNA of Bacillus CW1 isolate revealed $100 \%$ similarity to the $16 \mathrm{~S}$ rDNA of Bacillus licheniformis. This molecular identification confirms the biochemical identification of the CW1 isolate, as previously identified as $B$. licheniformis (unpublished data). The partial sequence of the 16S rDNA has been submitted to the GenBank with accession number JN967640.

Cloning and Expression of $\alpha-L$ Arabinofuranosidase Gene. In this work we have isolated $\alpha$-L-arabinofuranosidase genes from genomic DNA of two Bacillus species by means of the PCR-cloning approach. Ampilification of arabinofuranosidase genes of $B$. subtilis DB104 (abfAal) and B. licheniformis CW1 (abfAb3) revealed 1721 and 1739 bp DNA fragments, respectively. Restriction endonuclease analysis of the recombinant plasmids resulted in three DNA fragments consisting of undigested recombinant plasmids of 4736 or 4740 bp, a vector fragment of $2997 \mathrm{bp}$ and the inserted fragment of 1739 or 1743 bp confirming succesfull gene cloning (Fig 1A). The cloned genes were each expressed and assayed to confirm their Abfa activity. The recombinant enzymes demonstrated positive activity towards the specific substrate paranitrophenyl $\alpha$-L-arabinofuranoside indicated by the 

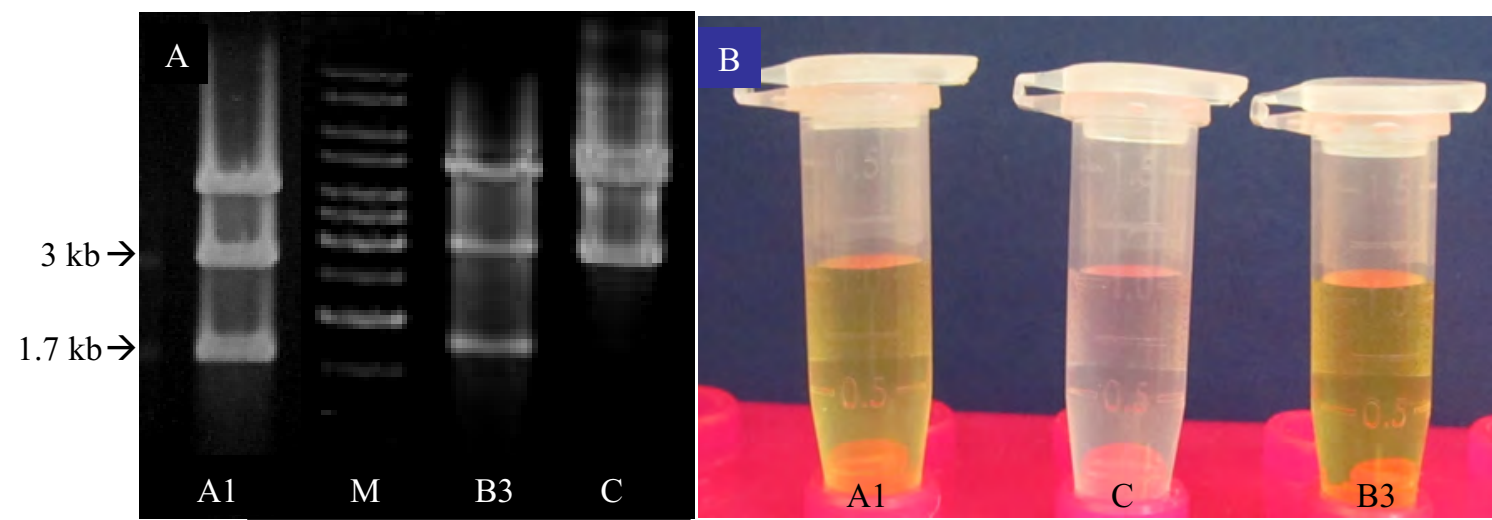

Fig 1 Verification of recombinant pGEM T easy plasmid harbouring abfa of B. licheniformis CW1 (A; line B3) and B. subtilis DB104 (A; line A1) by means of EcoRI restriction endonuclase analysis (A) and qualitative verification of the recombinant $A b f a$ activity by means of assays against specific substrate para-nitrophenyl arabinofuranoside (B). M: $1 \mathrm{~kb}$ DNA marker; C: negative control.

color change of the reaction mixtures from clear to a slightly yellow (Fig 1B). Two positive clones (A1 and B3) were chosen for further analysis of their nucleotide sequences and biochemical properties of the expressed Abfas.

Sequence Analysis of abfAal and $a b f A b 3$. Sequence analysis of the cloned abfAal and $a b f A b 3$ revealed the presence of an open reading frame of 1503 bp (abfAal) and $1509 \mathrm{bp}(a b f A b 3)$ for genes encoding a hypothetical protein of 500 and 502 amino acids of $\mathrm{AbfaA} 1$ and $\mathrm{AbfaB} 3$, respectively. Identification of those proteins by database enquiry using BLASTP tools (http://blast.ncbi.nlm.nih.gov/Blast.cgi) determined that the 500 and 502 amino acids proteins were $\alpha$-L-arabinofuranosidases which showed $100 \%$ identity to putative arabinofuranosidases of $B$. subtilis 168 and $B$. licheniformis ATCC 14580, respectively. The deduced amino acid sequence of AbfaB3 shares $75 \%$ identity with that of AbfaA 1 (Fig 3). No putative signal sequence was detected when amino acid sequences of the AbfaA1 as well as AbfaB3 were analysed using signal prediction tools SignalP V1.1 (available as public web server at http://www.cbs.dtu. $\mathrm{dk} /$ service/SignalP/), indicating that both arabinofuranosidases are intracellular enzymes.

Partial Characterization of Recombinant Arabinofuraosidases. Effect of temperature and $\mathrm{pH}$ on activity and stability of the recombinant Abfa were studied. The AbfaA1 and AbfaB3 were active at $\mathrm{pH}$ range of 6-8 and temperature of $30-70{ }^{\circ} \mathrm{C}$. AbfaB3 was relatively more tolerant to $\mathrm{pH}$ in comparison to $\mathrm{AbfaA}$. $\mathrm{AbfaB} 3$ retained its enzymatic activity in the $\mathrm{pH}$ range of 6-9, whereas that of AbfaA1 was active in the $\mathrm{pH}$ range of 6-8; however both enzymes showed maximum activity at pH 6 (Fig 2A). The enzymatic activity of AbfaA1 seemed to be relatively stable at temperatures below $50{ }^{\circ} \mathrm{C}$, but it decreased drastically at temperatures above $50{ }^{\circ} \mathrm{C}$ (Fig 2B). In contrast, enzymatic activity of $\mathrm{AbfaB} 3$ increased along with the increased reaction temperature to reach its maximum activity at $60{ }^{\circ} \mathrm{C}$. When incubated at their optimal pHs and temperatures, AbfaA $1\left(50{ }^{\circ} \mathrm{C}\right)$ retained less than $60 \%$ activity after $4 \mathrm{~h}($ Fig $2 \mathrm{C})$ while AbfaB3 $\left(60^{\circ} \mathrm{C}\right)$ maintained more than $75 \%$ activity after $12 \mathrm{~h}$. Employing the equation (1), the following inactivation equations of AbfaA1 and $\mathrm{AbfaB} 3$, respectively were obtained:

$\log (A)=-0.0475(t)+0.3385$ for $A b f a A 1$ at $50^{\circ} \mathrm{C}$

$\log (A)=-0.0095(t)+0.6000$ for $\mathrm{AbfaB} 3$ at $60^{\circ} \mathrm{C}$

based on equations (2) and ( 3 ), the D-value of $\mathrm{AbfaA} 1$ at $50{ }^{\circ} \mathrm{C}$ and $\mathrm{AbfaB} 3$ at $60{ }^{\circ} \mathrm{C}$ are 8 and $63 \mathrm{~h}$, respectively. The half life of both Abfas estimated by the corresponding equations (2) and (3) revealed $t_{1 / 2}$ values of $2 \mathrm{~h}$ (AbfaA1) and $19 \mathrm{~h}$ (AbfaB3). The predicted $t_{1 / 2}$ value of AbfaA 1 seemed to be shorter than the actual experimental data by about $4 \mathrm{~h}$ (Fig 2C).

\section{DISCUSSION}

A few arabinofuranosidases have been purified and characterized from the genus Bacillus. Examples are $B$. pumilus (Degrassi et al. 2003), B. polymyxa (Morales et al. 1995), B. stearothermophilus (Gilead and Shoham 1995; Bezalel et al. 1993), and B. subtilis (Kaneko et al. 1994). To our knowledge, this is the first report on an arabinofuranosidase characterization isolated from $B$. licheniformis. In this work, an arabinofuranosidase gene, $a b f a B 3$, was successfully isolated and cloned from $B$. licheniformis $\mathrm{CW} 1$. Identification of the arabinofuranosidase gene worked well using gene 
A

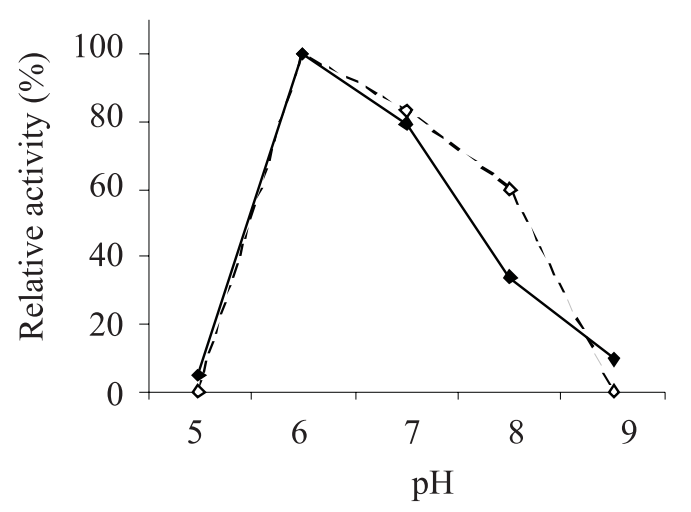

B

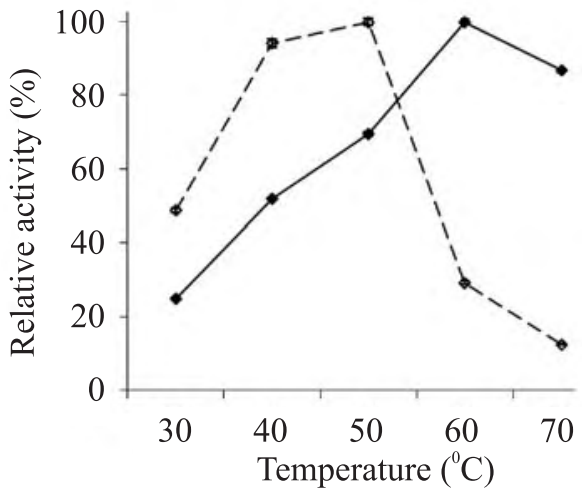

$\mathrm{C}$

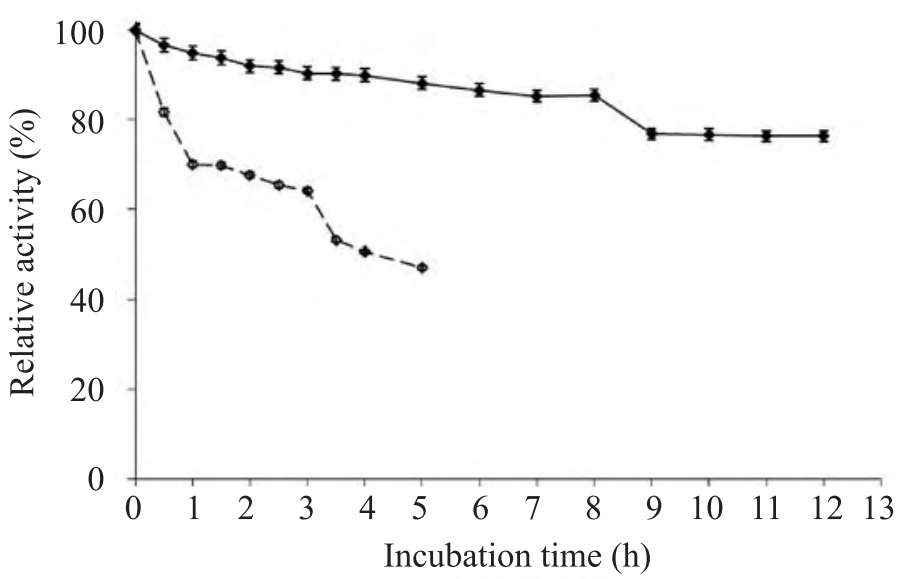

Fig 2 Properties of crude extracts of recombinant arabinofuranosidase originated from $B$. subtilis DB104, AbfaA 1 (-- - --) and $B$. licheniformis $\mathrm{CW} 1, \mathrm{AbfaB} 3(\neg)$ ). (A) The effect of $\mathrm{pH}$ on the recombinant Abfa activity in different buffers. The reaction $\mathrm{pH}$ range were adjusted between $5-9$ with the following buffers: $50 \mathrm{mM}$ citrate buffer (pH 5 to 6), phosphate buffer ( $\mathrm{pH} 7$ to 8), Tris-HCl buffer ( $\mathrm{pH}$ 9). The activity at optimal $\mathrm{pH}$ was defined as $100 \%$. (B) The effect of temperature on the activity of recombinant Abfa. The activity at optimal temperature was defined as $100 \%$. (C) The thermostability of recombinant $\mathrm{Abfa}$ at optimal $\mathrm{pH}$ and temperature. The initial activity was defined as $100 \%$. Standard deviations are indicated by bars.

specific primer (GSP) designed based on a putative $\alpha$ L-arabinofuranosidase of $B$. licheniformis ATCC 14580. A similar result was observed in the PCR cloning of arabinofuranosidase gene of B. subtilis DB104 using a pair of GSPs derived from a putative alpha-L-arabinofuranosidase gene of B. subtilis 168. This result indicates that the gene is highly conserved between strains of the same species, as previously demonstrated by Park et al. (2007), by means of degenerate primer PCR approach to amplify arabinofuranosidase gene from Bacillus-associated species.

The arabinofuranosidase activity was detected in the cytoplasmic fraction of recombinant E. coli containing either the $a b f A a l$ or $a b f A b 3$ gene, which had been confirmed not to contain signal peptides, as predicted in silico by SignalP IV tools (http://www.cbs. $\mathrm{dtu} . \mathrm{dk} /$ services/SignalP/). This was in accordance with the subcellular localization analyses of recombinant AbfA and abf 2 activities reported by Inacio et al.
(2008), which showed that both recombinant proteins were retained in the cytoplasm of $B$. subtilis. However, Abfa activity was detected in the cell-free culture broth of $B$. subtilis DB104 as well as B. licheniformis CW1 (data not shown) as was previously reported in $B$. subtilis 3-6 by Kaneko et al. (1994), in $B$. stearothermophilus T-6 by Gilead and Shoham (1995), and in B. pumilus by Degrassi et al. (2003). This phenomenon is in agreement with the study of $B$. subtilis extracellular proteome that indicates the presence of some extracellular enzymes without signal peptide (Antelmann et al. 2001). In 2005 Bendtsen et $a l$. proposed a non-classical protein secretion pathway to elucidate the presence of some functional cytoplasmic proteins in growth medium of some bacteria cultures such as M. tuberculosis (Hart and Horwitz 1997), Streptococcus pyrogenes (Rosch and Caparon 2004), and B. subtilis (Hirose et al. 2000). These non-classical secreted proteins often seem to have a cytoplasmic function as well as an extracellular 


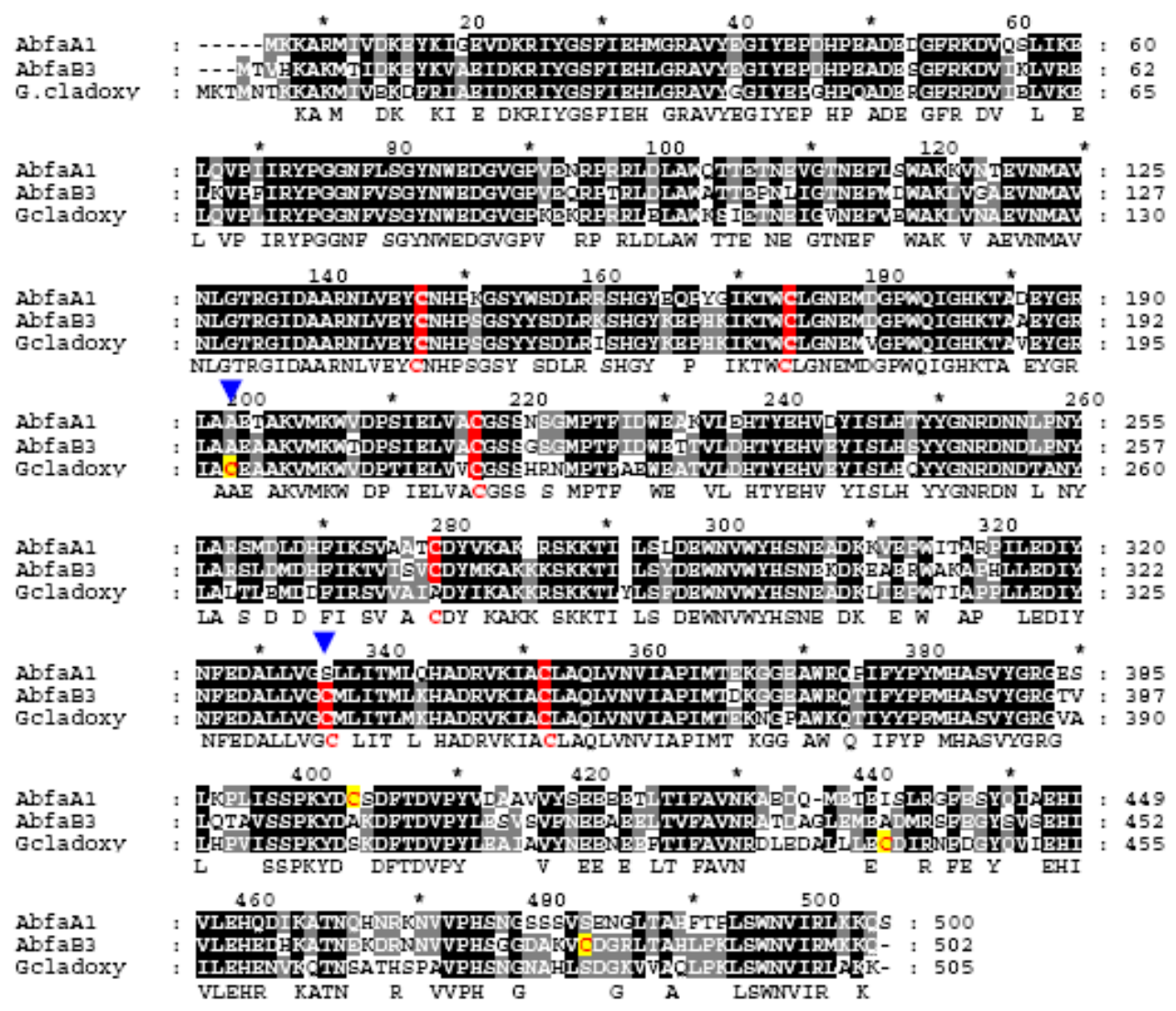

Fig 3 Alignment of the deduced amino acid sequences of the $\alpha$-L-arabinofuranosidase of B. subtilis DB104 (AbfaA1) and B. licheniformis CW1 (AbfaB3). Identical amino acids are indicated by black shades. Hyphens indicate gaps. Consensus sequence indicated below is based on the allignment of AbfaB3, AbfaA 1 and putative Abfas of B. amyloliquefaciens TA208 (NCBI-GI: 328554491), B. halodurans (NCBI-GI: 15614424), B. atrophaeus (NCBI-GI:311066968) as well as the known Abfas of Geobacillus stearothermophilus (NCBI-GI:122937809) and G. cladoxylolyticus (NCBIGI:113374907). The blue arrow head ( $\mathbf{v})$ indicates the Cys positions assumed to be crucial in the protein stabilization. The red blocked C (C) indicates conserved Cys whereas the yellow blocked Cys (C) indicates the unique Cys of the corresponding arabinofuranosidase.

role. However, in the case of B. licheniformis CW1 Abfa, cell lysis during exponential growth or during entry into the stationary phase cannot be excluded as a possible reason for the Abfa activity detected in the extracellular millieu. Further analyses such as subcellular localization or a control study using a cytoplasmic marker protein, such as isocitrate dehydrogenase (Gilead and Shoham 1995), should be conducted to discriminate the Abfa activity caused by cell lysis or secretion. Gonzales-Pastor et al. (2005) observed that $B$. subtilis is able to initiate lysis to surrounding cells as a mechanism to postpone sporulation. The activity of the two enzymes towards para-nitrophenyl-arabinofuranoside in various $\mathrm{pH}$ and temperature conditions shows that $\mathrm{AbfaB} 3$ is more stable at higher temperature $\left(60{ }^{\circ} \mathrm{C}\right)$ in comparison to AbfaA $1\left(50{ }^{\circ} \mathrm{C}\right)$. AbfaB3 is optimally active at $60{ }^{\circ} \mathrm{C}$ which is higher than the optimal temperature reaction of a thermostable Abfa from B. pumilus $\left(55^{\circ} \mathrm{C}\right.$; Degrassi et al. 2003), B. polymyxa $\left(55^{\circ} \mathrm{C}\right.$; Morales et al.
1995), or Butyryvibrio fibrisolvens $\left(50^{\circ} \mathrm{C}\right.$; Hespell et al. 1992), but lower than that of B. stearothermophilus L1 and T-6 $\left(70{ }^{\circ} \mathrm{C}\right.$; Bezalel et al. 1993; Gilead and Shoham 1995), Geobacillus caldoxylolyticus TK4 (75$80{ }^{\circ} \mathrm{C}$; Canakci et al. 2007), Thermotoga maritima MSB8 $\left(90{ }^{\circ} \mathrm{C}\right.$; Miyazaki 2005), and Thermobacillus xylanilyticus $\left(90{ }^{\circ} \mathrm{C}\right.$; Debeche et al. 2000). Based on these data it can be concluded that in terms of temperature stability, AbfaB3 is the second best enzyme among Bacillus arabinofuranosidase with a Dvalue of $63 \mathrm{~h}$ and half-life of $19 \mathrm{~h}$.

The primary structures of AbfaA 1 and AbfaB3 share $71 \%$ and $75 \%$ identity respectively to that of the characterized thermostable Abfa of G. caldoxylolyticus TK4 (Canakci et al. 2007). When the amino acid sequence of AbfaA1 and AbfaB3 were compared to that of G. cladoxylolyticus TK4 (AbfaTK4) in terms of cysteine content, AbfaA 1 has one less cysteines (6 Cys) than AbfaB3 and AbfaTK4 (7 Cys). All of them contain four conserved Cys residues (Cys147, Cys174, 
Cys216, and Cys351). The remaining non conserved Cys residues are located in different positions within each Abfa. One cysteine residue (Cys198) has a location which indicates it is essential in stabilizing the Abfa of G. cladoxylolyticus. This Cys198 is altered to alanine (Ala198) which is conserved among seven different Abfa's including AbfaA1 and AbfaB3 (Fig 3). This alteration (A198C) may lead to a possible formation of disulfide bond between Cys198 and Cys216 which could stabilize the protein conformation of AbfaTK4 resulting in 10 or $20{ }^{\circ} \mathrm{C}$ higher thermostability in comparison to AbfaB3 or AbfaA1, respectively. A similar phenomenon is observed between AbfaB3 and AbfaA1 sequences. One cysteine residue (Cys335) which is conserved in AbfaTK4 as well as AbfaB3, is altered to alanine (A335) in AbfaA1. This alteration $(\mathrm{C} 335 \mathrm{~A})$ is most probably responsible for the lower thermostability of AbfaA1 in comparison to AbfaB3, as the result of a possible loss of the disulfide bond formed between Cys335 and cys351. However further studies on site directed mutagenesis of either abfAal or abfAb3 should be carried out to support this hypothese since cysteine content is not the only factor to contribute to protein thermostabilization. The important role of Cys in the protein thermostability has been reported in the case of $\alpha$-amylase of Pyrococcus furiosus (Savchenko 2002), endoglucanase Cel12A of Humicola grisea (Sandgren et al. 2003), and manosidase of Aspergilus satoi (Tatara et al. 2005). In all these studies it is evident that substitution at Cys residue greatly decreased thermostability of the enzyme. In other studies, cysteine residues were introduced to form de novo disulfidebridges in order to improve thermostability of endoxylanase of $T$. reesei (Fenel et al. 2004) and B. stearothermophilus (Jeong 2007). Cysteine frequently forms a disulfide bond that stabilizes proteins by lowering their conformational entropy compared with their unfolded state (Zhang et al.2011).

Based on its relatively higher thermostability, the newly isolated and characterized arabinofuranosidase of $B$. licheniformis $\mathrm{CW} 1$ is potential to be applied in the degradation process of lignocellulose biomass in combination with thermostable xylanases, which usually conducted at high temperature (not less than 60 $\left.{ }^{\circ} \mathrm{C}\right)$ to produce xylooligosaccharides.

\section{REFERENCES}

Akpinar O, Erdogan K, Bostanci S. 2009. Enzymatic production of Xylooligosaccharide from selected agricultural wastes. Food and Bioprod Process. 87(2): 145-151. doi:10.1016/j.fbp.2008.09.002.

Antelmann H, Tjalsma H, Voight B, Ohlmeier S, Bron S, van Dijl JM, Hecker M. 2001. A proteomic view on genomebased signal peptide predictions. Genome Res. 11:14841502. doi: $10.1101 /$ gr. 182801 .

Bals B, Teachworth L, Dale B, Balan V. 2007. Extraction of proteins from switchgrass using aqueous ammonia within an integrated biorefinery. Appl Biochem Biotechnol. 143(2):187-198.

Bendtsen JD, Kiemer L, Fausboll A, Brunak S. 2005. Nonclassical protein secretion in bacteria. BMC Microbiol. 5. [on line]. doi:10.1186/1471-2180-5-58.

Bezalel L, Shoham Y, Rosenberg E. 1993. Characterization and delignification activity of a thermostable $\alpha$-Larabinofuranosidase from Bacillus stearothermophilus. Appl Environ Microbiol. 40:57-62.

Bradford MM. 1976. A rapid and sensitive method for thequantitation of microgram quantities of protein utilizing the principle of protein-dye binding. Anal Biochem. 72:248-254.

Canakci S, Belduz AO, Saha BC, Yasar A, Ayaz FA, Yayl N. 2007. Purification and characterization of a highly thermostable $\alpha$-L-Arabinofuranosidase from Geobacillus caldoxylolyticus TK4. Appl Microbiol Biotechnol. 75:813-820. doi:10.1007/s00253-0070884-1.

Debeche T, Cummings N, Connerton I, Debeire P, O'Donohue MJ. 2000. Genetic and biochemical characterization of a highly thermostable $\alpha$-Larabinofuranosidase from Thermobacillus xylanilyticus. Appl Environ Microbiol. 66(4):17341736. PMCID: PMC92053.

Degrassi G, Vindigni A, Venturi V. 2003. A thermostable alpha-arabinofuranosidase from xylanolytic Bacillus pumilus: purification and characterisation. J Biotechnol. 101(1): 69-79.

Dhiaf A, Bakhrouf A, Witzel K. 2008. Resuscitation of eleven-year VBNC Citrobacter. J Water Health. 6(4): 565-568.

Fenel F, Leisola M, Jänis J, Turunen O. 2004. A de novo designed N-terminal disulphide bridge stabilizes the Trichoderma reesei endo-1,4- $\beta$-xylanase II. J Biotechnol. 108:137-143.

Gilead S, Shoham Y. 1995. Purification and characterization of alpha-L-arabinofuranosidase from Bacillus stearothermophilus T-6. Appl Environ Microbiol. 61(1):170-174. doi: 0099-2240/95/04.0010.

Gonzalez-Pastor JE, Hobbs EC, Losick R. 2003. Cannibalism by sporulating bacteria. Science 301(5632):510-513.

Hespell RB, O'Bryan PJ.1992. Purification and Characterization of an $\alpha$-L-Arabinofuranosidase from Butyrivibrio fibrisolvens GS113. Appl Environ Microbiol. 58(4):1082-1088. doi 00992240/92/041082-07\$02.00/0

Hirose I, Sano K, Shioda I, Kumano M, Nakamura K, Yamane K. 2000. Proteome analysis of Bacillus subtilis 
extracellular proteins: a two-dimensional protein electrophoretic study. Microbiology 146(1):65-75.

Hunhammar M, Faulds CB, artolome B, Williamson G. 1997. Novel biotransformations of agro-industrial cereal waste by ferulic acid esterases. Ind Crops Prod. 6:367-374. doi:10.1016/S0926-6690(97)00027-7.

Inacio JM, Correia1 IL, de Sa'-Nogueira I. 2008. Two distinct arabinofuranosidases contribute to arabinooligosaccharide degradation in Bacillus subtilis. Microbiology 154:2719-2729. doi: 10.1099/mic.0. 2008/018978-0.

Jeffries TW. 1990. Biodegradation of lignin-carbohydrate complexes. Biodegradation 1(2-3):163-176. doi:10.1007/BF00058834.

Jeong MY, Kim S, Yun CW, Choi YJ, Chob SG. 2011. Engineering a de novo internal disulfide bridge to improve the thermal stability of xylanase from Bacillus stearothermophilus No. 236. J Biotechnol. 127(2):300-309.

Kaneko S, Sano M, Kusakabe I. 1994. Purification and some properties of alpha-L-arabinofuranosidase from Bacillus subtilis 3-6. Appl Environ Microbiol. 60(9):3425-3428. doi:0099-2240/94/04.00+0.

Keshwani DR, Cheng JJ. 2009. Switchgrass for bioethanol and other value-added applications: a review. Bioresour Technol. 100: 1515-1523. doi.org/10.1016/j.biortech. 2008.09.035.

Martinez C, Gertosio C, Labbe A, Perez R, Ganga MA. 2006. Production of Rhodoturola glutinis: a yeast that secretes $\alpha$-L-arabinofuranosidase. Electron J Biotechnol. 9(4):407-413. [on line]. doi:10.2225/vol9-issue4fulltext-8.

Miyazaki K. 2005. Hyperthermophilic $\alpha-L$ arabinofuranosidase from Thermotoga maritima MSB8: molecular cloning, gene expression, and characterization of the recombinant protein. Extremophiles 9(5):399-406. doi:10.1007/s00792-0050455-2.

Morales P, Sendra JM, Gonzales P. 1995. Purification and characterization of an arabinofuranosidase from Bacillus polymyxa expressed in Bacillus subtilis. Appl Microbiol Biotechnol. 44(1-2): 112-117. doi:10.1016/0141-0229(94)00062-V.

Nicholas KB, Nicholas HB. 1997. GeneDoc: a tool for editing and annotating multiple sequence alignments. http://www.psc.edu/biomed/genedoc.

Park JM, Han NS. 2007. Rapid detection and isolation of known and putative alpha-L-arabinofuranosidase genes using degenerate PCR primers. J Microbiol Biotechnol. 17(3):481-489.

Pei J, Shao W. 2008. Purification and characterization of an extracellular alpha-L-arabinosidase from a novel isolate Bacillus pumilus ARA and its over-expression in Escherichia coli. Appl Microbiol Biotechnol. 78(1):115-121. doi:10.1007/s00253-007-1295-z.

Raweesri PP, Riangrungrojana. 2008. Alpha-LArabinofuranosidase from Streptomyces sp. PC22: purification, characterization and its synergistic action with xylanolytic enzymes in the degradation of xylan and agricultural residues. BioresourTechnol. 99(18):8981-8986.

Rosch J, Caparon M. 2004. A microdomain for protein secretion in Gram-positive bacteria. Science 304:15131515. doi: 10.1126/science.1097404.

Ross NW, Johnson KG, Braun C, MacKenzie CR, Schneider H. 1992. Enzymatic hydrolysis of water-soluble lignincarbohydrate complexes from Populus deltoiedes: effect of combinations of $\beta$-mannanases, xylanase and acetyl xylan esterase. Enzyme Microb Technol. 14:90-95.

Saha BC, Bothast RJ.1999. Production of 2,3-butanediol by a newly isolated Enterobacter cloacae. Appl Microbiol Biotechnol. 52:321-326. doi: 10.1007/s002530051526.

Sambrook J, Russell DW. 2001. Molecular cloning a laboratory manual vol 1. $3^{\text {rd }}$ ed. Cold Spring Harbor Laboratory Press: Cold Spring Harbor, New York.

Sanchez O,Cardona CA. 2008. Trends in biotechnological production of fuel ethanol from different feedstocks. Bioresour. Technol. 99:5270-5295. doi:10.1016/ j.biortech.2007.11.013.

Sandgren M, Gualfetti PPJ, Paech C, Paech S, Shaw A, Gross LS, Saldajeno M, Berglund GI, Jones TA, Mitchinson C. 2003. The Humicola grisea Cel12A enzyme structure at $1.2 \AA$ resolution and the impact of its free cysteine residues on thermal stability. Prot Sci. $12: 2782-2793$

Savchenko A, Vieille C, Kang S, Zeikus JG. 2002. Pyrococcus furiosus $\alpha$-Amylase is stabilized by calcium and zinc. Biochemistry 41: 6193-6201.

Tatara Y, Yoshida T, Ichishima E. 2005. A single free cysteine residue and disulfide bond contribute to thermostability of Aspergillus saitoi 1,2- $\alpha$-Mannosidase. Biosci Biotechnol Biochem. 69(11): 2101-2108. doi:10.1271/bbb.69.2101.

Thompson JD, Higgins DG, Gibson TJ. 1994. CLUSTAL W: improving the sensitivity of progressive multiple sequence alignment through sequence weighting, position-specific gap penalties and weight matrix choice. Nucleic Acids Res. 22(11):4673-4680. doi: 10.1093/nar/22.22.4673.

Wahyuntari B, Suhartono M. 2002. Thermostability of an extreme thermophilic extracellular protease bacterium Bacillus TPS2d from Tangkuban Perahu. Hayati 9(4):114-118.

Whitehead TR,Hespell RB. 1990. The genes for three xylandegrading activities from Bacteroides ovatus are clustered in a 3.8-kilobase region. $\mathrm{J}$ Bacteriol. 172(5):2408-2412.

Zhang L, Chou CP, Moo-Young M. 2011. Disulfide bond formation and its impact on the biological activity and stability of recombinant therapeutic proteins produced by Escherichia coli expression system. Biotechnol Adv. 29: 923-929. doi:10.1016/j.biotechadv.2011.07.013. 